\title{
Culture in the Name of the People? Towards a typology of populism and culture
}

\author{
Judith Jansma \\ UNIVERSITY OF GRONINGEN \\ j.f.jansmårug.nl
}

Received: 26/02/2019

Accepted: 10/09/2019

\begin{abstract}
Populism is a topic that has been widely studied over the past decades but mostly from a political perspective. These contributions mainly focus on the analysis of populism as a (socio) political phenomenon placed in a historical, global context. A second field of interest covers the mass appeal of populist parties. The latter is not only a timely, highly relevant issue right now but also sheds light on the flaws of liberal democracy.

While a lot of academic effort has been put into defining populism and explaining the reasons for its success, the underlying cultural beliefs on which populist "us and them" dichotomies are based remain unclear. We shall therefore come up with a typology of culture and populism. This typology will reveal how various aspects of culture (such as popular culture, cultural images, and literary works) are prevalent in the populist construction of 'us' and 'them'.

Based on examples from France and The Netherlands (two countries with major right-wing populist parties), the typology will differentiate between sociofacts, mentifacts and artifacts (cf. Huxley), and their use and appropriation by populist actors. The artifacts category comprises what I call 'organic authors' and 'appropriated authors', a terminology borrowed from Gramsci. The difference between the two, as will be shown, is the author's identification with and articulation of certain kinds of ideas.

Keywords: cultural studies, populism, cultural identity, France, The Netherlands.
\end{abstract}

Corresponding author: J.F. (Judith) Jansma, Faculty of Arts. European Literature and Culture-Centre Arts in Society. Oude Kijk in't Jatstraat, 26. 9712 EK Groningen (Holand).

Suggested citation: Jansma J. (2019). Culture in the Name of the People? Towards a typology of populism and culture. Debats. Journal on Culture, Power and Society, 4, 119-132. DOI: http://doi.org/10.28939/iam.debats-en.2019-10

\section{INTRODUCTION}

"If you believe that you are a citizen of the world, you are a citizen of nowhere. You don't understand what citizenship means". This famous statement made by Theresa May shortly after the Brexit vote ${ }^{\mathbf{1}}$ exemplifies

1 Theresa May's conference speech in full : https://www. telegraph.co.uk/news/2016/10/05/theresa-maysconference-speech-in-full/ the centrality of cultural identity in contemporary politics. The notion and alleged importance of the culturally-grounded national identity has made a strong come-back in today's political discourse, not only among the parties of the populist right, but also on a much broader scale. For instance, in their manifesto for the 2017 General Election, the Dutch Christian-Democratic Party (CDA) insisted that children should learn the Dutch national anthem and its 
history at school. This policy was incorporated in the final agreement of the coalition government, of which CDA is part. Hence, it can be said that adherence to a national identity is presented as a way of dealing with complex societal challenges such as multiculturalism and globalisation.

At the same time, culture is also used to convey a political standpoint. A good example is PVV leader Geert Wilders's's recent attempt to set up a Muhammad cartoon competition, which was cancelled after mass demonstrations in Muslim countries, most notably in Pakistan. It is clear that in this case the aim was not to celebrate culture through artistic expression but rather to use it as a political stick to stir up a hornets' nest, for it is well known that Muslims consider pictorial representations of The Prophet as blasphemous. Wilders admitted that he cancelled the competition to protect Dutch citizens from the wrath of Muslims, whom he considers to be violent and intolerant.

Culture and politics are a fruitful combination, as culture is key in building a feeling of community within a geopolitically-defined space (the nation). Following Anderson (2016), the nation should be considered "an imagined political community", in which a group too large for all members to know each other still experiences a bond, a "horizontal comradeship" primarily based on a common culture. As we have seen in the examples above, culture can be a set of common values and traditions that help define who "we" are but it can also be used to stir up hostility towards "others". This approach fosters a political worldview, with culture being used to underline a given political agenda.

This paper will propose a framework for understanding the role that culture plays in contemporary politics by focusing on populist parties. Having a strong 'us and

2 Geert Wilders is the leader of the Dutch Partij voor de Vrijheid (Freedom Party), a far-right populist party established in 2005 Wilders is particularly known for his anti-Islam discourse, for which he has been tried several times. In 2016 he was found guilty of incitement to discrimination and hatred targeting Dutch citizens of Moroccan decent. them" narrative, in which society is split into 'good' and 'bad', is largely built upon a cultural understanding of a common identity. Following Rensmann (2017), I will argue that this notion of a culturally-based identity is strongly articulated by populist parties. That is why I will analyse the ways in which populists explicitly use culture. This will follow a brief introduction on populism and its dichotomies.

Given that culture is a fairly broad concept, I shall propose a typology covering the various kinds of culture and their use by populists. This can range from cultural images and symbols - a more folkloric interpretation of culture - to the use and appropriation of cultural works such as literature, cinema and art. This approach - as advocated by Rensmann (2017) — should shed light on populism as a mostly cultural, authoritarian reaction to modern society.

After the first, more general part in which I define populism, the scope will be narrowed down to the contexts of France and The Netherlands. These two countries have sizeable populist parties, which closely work together as allies in the European Parliament. Being opposed to (further) European integration and immigration, these parties strongly defend national sovereignty and identity, and, for this reason, provide interesting case studies.

\section{WHAT IS POPULISM?}

If 2016 marked the global breakthrough of populism, with the Brexit vote in June and Donald Trump's election in November, the populist storm does not seem to have abated. The so-called 'Patriotic Spring' of 2017 temporarily halted in France and The Netherlands, although both the Front National (FN) and the Partij voor de Vrijheid (PVV) still ended second during their respective presidential and legislative elections. A populist 'Autumn Storm' reached Germany in September 2017, where Alternative für Deutschland (AfD) was the first nationalist far-right party to win seats in the Reichstag/Bundestag since World War II. Only one month later almost $26 \%$ of the Austrian electorate 
voted for the right-wing populist Freiheitliche Partei Österreichs (FPÖ), which is now part of Austria's coalition. In 2018, several European countries experienced a spate of populist electoral gains, most notably in Italy, Hungary, Slovenia and Sweden. Outside Europe, there was the widely disputed re-election of president Maduro in Venezuela, followed by the election of Bolsonaro in Brazil later that year. In other words, it is clear that populism is still a political force to be reckoned with both in Europe and beyond.

The rise of populism has also attracted considerable scholarly interest, as shown by the number of recent contributions on the topic, most notably the publication of Mudde and Kaltwasser's Populism, A Very Short Introduction in 2017. Most scholars try to define what populism is, given that the word is used to describe very broad political phenomena in widelyscattered geographical areas embodying different political traditions (ranging from Latin American leftwing presidents to European far-right parties) (Mudde and Kaltwasser 2017). Consequently, there seems to be little consensus on whether populism is an ideology, a movement, a political style or a discourse. For the purpose of this paper, I will stick to Mudde's (2004) minimalist definition of populism, which takes into account the core concepts that all populisms share, while at the same time acknowledging the various forms these movements take. Mudde and Kaltwasser (2017: 6) define populism as follows:

Populism is a thin-centred ideology that considers society to be ultimately separated into two homogeneous and antagonistic camps, the 'pure people' and 'the corrupt elite', and which argues that politics should be an expression of 'The People's Will'.

This definition, or ideational approach, sees populism as a 'thin-centred' ideology, in contrast to a 'full' ideology, meaning that it can be combined with other ideologies. If populism determines the presence of the three core concepts, the 'host-ideologies' define the way in which they are interpreted. For example, if populism is merged with Socialism, being part of the people or the elite is mostly a socio-economic question, as we see for example in countries such as Venezuela and Bolivia, or in Europe in left-wing populist parties such as Podemos in Spain and Syriza in Greece. On the other hand, when populism is combined with nativism, the people is constituted on an ethnic base, for example the 'real' French, Hungarians or Americans, excluding minorities such as Roma (gypsy) or (Muslim) immigrants.

Another much debated issue is why people vote for populist parties, and, more specifically, what has encouraged them to do so in such large numbers now. As argued by Laclau in his influential work $O n$ Populist Reason (2005), populism emerges when there is a "multiplication of social demands". However, these social demands, or "neglected concerns" (Judis 2016) are numerous and are therefore often categorised in terms of society's existing social and cultural fault lines (Kriesi et al. 2006, Rensmann 2017, Rodrik 2017). In general, one can say that populist voters revolt against the establishment because they have a burning sense of injustice or feel that their way of life is threatened. That said, the precise nature of these (perceived) challenges may differ among countries, regions and probably even among individuals.

The populist worldview simplifies a complex reality, explaining the problems of an imagined homogeneous people by blaming the elite and by scape-goating the 'others'. This idea of antagonism is key to theories on populism, resulting in horizontal and vertical dichotomies (Rensmann 2017). The vertical dichotomy - between the people and the elite - is an essential part of populism. Populists argue that the elite (which can be a political, economic, or cultural one) is alienated from the ordinary folk (Rooduijn et al. 2016), and therefore does not represent the people anymore. This, according to the populist view, is the world upside down; the idea of popular sovereignty implying that the will of the people or general will should be decisive. In her 2017 campaign video $^{3}$, Marine Le Pen, leader of the French far-right party Front National,

3 Clip from Marine Le Pen's official campaign: https://www. youtube.com/watch?v=FYWnuQc5mYA 
illustrates this antagonism when telling her audience that the choice they will be making for the elections is crucial, in her own words, "un choix de civilisation" [a choice of civilisation]. Either they continue “(...) with those who lied, failed, betrayed, who misled the people and who lost France", or they decide "(...) to put France back in order". The slogan of the campaign being "Au nom du peuple" [In The People's Name]. It is not hard to guess who those liars and traitors are, and why the French people need Marine Le Pen for France to be "independent, respected, prospering, proud, sustainable and just".

As well as setting the people against the elites, most populists tend to exclude an 'other' from being part of the people. This mechanism is referred to as the "horizontal dichotomy" (Rensmann 2017) or "exclusionism" (Rooduijn et al. 2014). While some scholars argue that this exclusion of a dangerous 'other' is purely a characteristic of right-wing populism (Judis 2016, Mudde 2013, Rooduijn et al. 2014), Rensmann (2017: 126) disagrees and states that this exclusionary discourse is also found in populist parties that are generally classified as leftwing. Here, he points to the German Die Linke and La France Insoumise which - although being situated at the (far) left of the political spectrum - do openly defend a nationalist agenda. He adds that the leftright classification is the wrong tool for typifying the various kinds of populism, and suggests that we look at other aspects:

Despite their cross-national distinctions, however, all 'right-wing' and most 'left-wing' populist actors share key common ideological denominators shaped by authoritarianism, anti-liberal, antipluralistic vertical and horizontal dichotomies, which implicitly or explicitly endorse cultural exclusivity, identity and denigration of 'others'.

In other words, and to come back to Mudde's (2004) definition of populism as a thin-centred ideology, whether a populist party is left-wing or right-wing does not determine their adoption or rejection of nativist ideas. Actually, the mere fact that populism aims at an imagined homogeneous people suggests that some sort of exclusion is inherent in the populist view given that such homogeneous peoples are a figment of the imagination and are thus created by excluding members that look different or behave differently.

Like the vertical dichotomy (in which populists stress the gap between the people and the elite, and, importantly, also the elite's unwillingness to narrow it), the horizontal dichotomy is also multi-layered. According to populist ideas, the 'other' constitutes a serious threat to the imagined homogeneous people, implying that 'the people' is morally good and the 'other' inherently evil. It is also important to note that the 'other' is projected as a homogeneous entity, just like 'the people' and 'the elite'. Evidently, this homogenisation of the 'other' is highly problematic, especially when talking about groups such as 'immigrants' or 'refugees', which obviously comprise people from varying nationalities, religions, socioeconomic backgrounds and education. By defining an out-group, a self-group is formed on the basis of a dichotomy: 'they are lazy immigrants' versus 'we are hard workers'. Excluding the other helps thus to build one's own (national) identity (cf. Wodak 2015).

My assumption is that this double 'us and them' mechanism (which is a feature of the populist mind set) builds upon and contributes to a cultural understanding of the people's common identity. That is why this paper will focus on the links between populism and culture. Often thought to be mutually exclusive (populism dismisses culture as a waste of time and money, while culture perceives and represents populism as its disturbing 'other'), I will argue that things are much more complex. The next section will give an overview of (recent) scholarly contributions on the topic of populism and culture, after which I will focus on the use and appropriation of culture by populists.

\section{POPULISM AND CULTURE}

In 2006, Kriesi et al. mentioned the prevalence of cultural factors over economic ones in the populist right's agenda, and in recent academic contributions 
this idea has taken root. In their paper, Kriesi et al. (2006) conclude that "parties of the populist right do not stand out for their economic profile" and that "it is on cultural issues where they support a demarcation strategy much more strongly than (untransformed) mainstream parties". Focusing on the populist right, they claim that this emphasis on cultural issues is a much more powerful way of uniting a large group of disillusioned people from widely differing economic groups.

This idea of both an economic and a cultural cleavage is also present in Rodrik (2017), who splits people into the 'winners' and 'losers' of globalisation. If the former is a characteristic of left-wing populism, in which the schism between working class and (financial) elites is accentuated, the latter exploits the cultural gap based on the identity of the 'people' versus outside groups such as immigrants and technocratic institutions (EU), raising the spectre new 'competitors'. The division between economic and cultural factors explaining the populist vote can also be found in Gidron and Hall (2017: 6), who look at the populist right. Taking one's 'subjective social status' as their main focus, they assume that both socio-economic developments as well as new cultural frameworks (i.e. multiculturalism, gender equality) make many feel that they are no longer respected and recognised by society. Also Goodhart's (2017: 9) distinction between 'Somewheres' and 'Anywheres' points to ordinary people's feeling of inferiority in comparison with others (the elite). He claims that mainly cultural values lie at the heart of the dissent stemming from this:

Their appeal [i.e. of populist politics] is primarily motivated by cultural anxiety and hard-to-measure psychological loss. Economic loss is a factor tooa significant majority of the 56 per cent of British people who describe themselves as 'have-nots' voted Brexit but if it [the Referendum] had been primarily about economic loss, the populists of the left would surely have been stronger.

These different sets of cultural values (progressive versus conservative) provoke cultural clashes; a "cultural backlash" (Inglehart and Norris 2016), "culture wars" (Furedi 2018, Nagle 2017), or in Rensmann's (2017) words, a "cultural counter-revolution". As such, populism speaks to the people whose voices once belonged to the dominant cultural normative discourse but that are now overruled by those advocating progressive social values.

The cultural clash can also take place on an international level. Furedi (2018) describes "conflicting attitudes towards cultural values" between Hungary, led by a conservative right-wing populist party, and the EU. At the same time, many Western European populist parties have a strong tendency to contrast 'our' modern Western values to those of the 'other', usually an Islamic culture, considered backward (Brubaker 2017, Moffitt 2017). An "Identitarian Christianism" is defended, a common Western European 'culture' which includes liberal progressive values such as gender equality, gay rights, secularism and freedom of speech versus the allegedly intolerant Islam. These examples clearly show that culture is an essential tool for mobilising people, playing on the people's discontent with changing cultural values.

The term 'populism' also appears in the Cultural Studies field, most notably in relation to popular culture. McGuigan (1992: 4) invokes the notion of "cultural populism", seeking to underline the importance of studying the symbolic experiences and practices of ordinary people in contrast to 'culture with a capital C". A parallel can be seen between this neo-Gramscian conception of cultural studies and the vertical dichotomy of the people opposed to the elite. Here, it is worth mentioning the literary phenomenon of le roman populiste in early 1930s France, (Paveau 1998). According to the authors of the two manifestos, Thérive and Lemonnier, people should have a central place in the narrative: "one should depict the little people, the mediocre people, who are the mass of the society, and whose lives also have their dramas" (Lemonnier 1930, quoted in Paveau 1998: 48).

More recently, Bax (2016) adopted the term "literary populist" to describe the work of Dutch novelist Leon de Winter, who uses populist rhetoric to position 
himself both as a public intellectual and a literary celebrity. The public intellectual writes columns for newspapers and is invited to talk shows as a political commentator. By contrast, the literary celebrity seeks commercial success, writing books that are no more than entertainment. Supported by his reading public (the people) and denounced by literary critics (the elite), Bax writings echo the discourse and rhetoric of populist politicians - something that is also reflected in De Winter's political novels.

All three authors share this wish to identify with the people and their way of life because they see them as more 'authentic'. However, while using the term 'populism', it should be made clear that this interpretation of populism does not follow Mudde's (2014) definition of the phenomenon (cf. above) but rather merely highlights some of its key aspects. In the case of the roman populiste, the emphasis is on the people - a borrowing from the Russian narodniki (populists) in the late $19^{\text {th }} /$ early $20^{\text {th }}$ century. Bax, on the other hand, focuses on the populist rhetorical tools of simplification and polarisation that are part and parcel of De Winter's oeuvre. This indicates the extent to which populism has become an ambiguous term, used across different disciplines, and reminds us that we should be aware of its diverse uses and meanings.

Rather than echoing a political phenomenon, culture can sometimes help us understand or reflect on complex (political) realities and the cultural values at stake. Here, the so-called 'Trump bump' comes to mind, that is, the sudden popularity of certain dystopian novels after Donald Trump's election as President of The United States. Shaw (2018) and Rau (2018) examine the appearance of a new literary genre of post-Brexit novels (BrexLit) and the lessons to be learnt from them. In a similar vein, according to Berg-Sørensen (2017), culture can serve as a "diagnosis of a current ideological crisis in European democratic culture". Working on the controversial novel Soumission (2015: 143) by Houellebecq, he notes that the author uses satire to "expose, mock, make us laugh, unmask, and, thus, criticise those in power and with authority.".
In sum, we have seen that culture and populism are studied in relation to each other, but that there are different ways to do so. The most frequent link is the cultural discontent fuelling the success of populism. Rather less studied are the parallels between populism and popular culture, and the role of culture and literature as a way to critically reflect on the world. However, the use of culture made by populists has received scant attention. An earlier case study revealed that the novel Soumission was held up by members of the Front National and right-wing journalists as a dire warning and to urge their audiences to vote for a way out (Jansma 2018). The following section will draw up a typology of populism and culture to give a clearer picture of how populist parties appropriate culture for their own ends.

\section{TOWARDS A TYPOLOGY OF POPULISM AND CULTURE}

Before moving on to analysing the populist cultural narrative, one should reflect on the notion of culture and in particular on the ways it can provide a useful tool for populists. Following Hall (1986: 26), culture includes "the actual grounded terrain of practices, representations, languages and customs of any specific society. I also mean the contradictory forms of "common sense" which have taken root and helped to shape popular life.". This anthropological approach implies that culture is a system of "shared social meanings" (Barker 2000: 8), as opposed to the concept of 'Culture with a capital C' (cf. Leavisism). This latter (elitist) interpretation of culture sees it as "the best that has been thought and said in the world" (Arnold 1960, quoted in Barker 2000: 36). In other words, the opposition between 'high' and 'low' culture bears on whether culture is seen as "the high point in civilization" (Barker 2000: 36), or the product of ordinary life.

Traditionally, three types of culture can be distinguished (Barker 2000, McGuigan 1992, Nachbar and Lause 1996): elite culture, popular culture and folk culture. Whereas the latter is an oral transmission of artifacts — including legends and family recipes - within a limited community (family, friends), the other two 
are of a more public nature. The main difference between popular and elite culture, according to Nachbar and Lause (1996: 16), is that the former is produced on a large scale and that it aims to reach a mass audience. Elite culture, on the other hand, targets a more exclusive audience, having specific interests or knowledge. The authors stress their conviction that intelligence and wealth are not essential ingredients for elite culture:

"Elite" is specialised and limited to those interested enough to learn the specific knowledge needed, but not merely the culture of the rich and intellectual.

Evidently, this distinction between folk, popular and elite culture is a blurred one.. A director of an Art film will try to sell as many tickets as he can. A Bach fan would probably need to hear a lot of pop music before he could appreciate it, and vice-versa. This shows the inherent limitations of trying to pigeonhole the complex concept of culture into clear-cut (hierarchical) categories, and explains the endless argument about what constitutes art. Although this classification of culture is far from ideal, it does give us a good starting point for the negotiation of power and culture. Here the Gramscian concepts of ideology and hegemony come into play, in other words, the notion that the dominant ideas are the ideas of the ruling class. Given that ideology and hegemony are unstable factors, culture is "a terrain of conflict and struggle over meanings" (Barker 2000: 60-61). Popular culture is highly relevant when it comes to ideology and hegemony, as it is built upon what Gramsci calls "good sense" or a "cultural mindset" (Nachbar and Lause). The study of popular culture focuses less on the aesthetic value of an artifact and more on the cultural beliefs and values underlying it and how people react to it. It is easy to see the parallel between this neo-Gramscian conception of cultural studies and the vertical dichotomy of the people and the elite. This has been and is still a topic of interest in the study of populism (cf. Hall 1985; 1986, Laclau 2005, Hart 2012). However, before looking into several examples of populist uses of culture, we need to analyse the mechanisms for creating a national identity on the basis of shared values and beliefs.

If, as Anderson states, we consider a community to be mainly culturally-based and if we interpret culture as the whole set of shared values and beliefs, then the question is how this applies to populist discourse. As discussed above, populism is a thin-centred ideology and is based on the three core concepts of the people, the elite, and the general will. I have claimed that the concept of a homogeneous people is inherently exclusive, and based on the principles of a common culture. This cultural component is therefore not limited to the far right but it is more explicitly expressed by parties with a strong nativist character, such as the Front National (FN) and the Partij voor de Vrijheid (PVV). Besides an alien 'other', seen as a threat to the people's national culture, the elite is demonised for not being able or willing to stop the country losing its identity. In a speech at the Estivales de Fréjus [Fréjus Summer Festival] in September 2016 Marine Le Pen articulated the purely cultural bond between the French people:

We are the French nation. Millions of us are linked by unseen, unbreakable bonds, united by love for our country, our language, our culture. The nation's hearts beat as one, and we share the same breath, the same hope. (Marine Le Pen, $18^{\text {th }}$ September 2016)

Culture in this case is a tool to unite the people through common denominators. It is distinctive, because it allows the people to define themselves as French, and set themselves apart from other peoples (for instance, the British, the Germans). Not only is culture a way of defining the self but it is also quintessential of the people's existence and its values: What is France if it is not a free, non-aligned nation that upholds the rights of each of the world's peoples to choose their own destiny? (Marine Le Pen, 18th September 2016). The question is clearly rhetorical, highlighting the idea that

4 Discours de Marine Le Pen aux Estivales de Fréjus: https://www.rassemblementnational.fr/videos/discoursde-marine-le-pen-aux-estivales-de-frejus/ 
without the populist definition of culture, the notion of Frenchness is nothing but a hollow shell. A transformation of the system of shared values and beliefs inevitably leads to a loss of the identification with - and thus distinctive function of - the culture, and even a detachment from the achievements of the democratic state such as Liberty, Equality and Fraternity. This is closely linked to the third and last implication of the populist definition of culture, namely its hegemonic character. According to the populists, other cultures, most notably non-European ones, are intrinsically backward; see the following quote by Geert Wilders during a Pegida ${ }^{5}$ meeting in Dresden, Germany ${ }^{\mathbf{6}}$ : "Our own culture is the best one. Immigrants should accept our values, not the other way around. (Geert Wilders, 13th April 2015). This ties in with the notion of Leitkultur - the leading culture of a country - that newcomers should assimilate (cf. Ossewaarde 2014). Interestingly, Wilders regards German and Dutch cultures as equally good, as they are both founded in the so-called Judeo-Christian tradition. He contrasts them with immigrant cultures, implicitly pointing to Islam, which threatens our allegedly superior Western European cultures.

The examples above show how populist leaders argue that culture is not only unique to each people but also quintessential and strongly hegemonic. That said, it is still not clear how this translates into a populist cultural narrative. This issue will be the main focus of the following section.

\section{THE POPULIST CULTURAL NARRATIVE}

In order to distinguish between these ideas and traditions on the one hand, and specific products on the other, I shall use Huxley's (1955: 17) terminology of

5 Acronym of Patriotische Europäer gegen die Islamisierung des Abendlandes (Patriotic Europeans against the Islamisation of The West), a far right-wing movement originally founded in Dresden (Germany) in 2014

6 Pegida speech Geert Wilders, 13th April 2015: https:// www.pvv.nl/36-fj-related/geert-wilders/8286-speech-gwpegida-130415.html sociofacts, mentifacts, and artifacts. The first two apply to what he calls social and mental constructions, such as kinship and political and economic institutions in the case of sociofacts, and symbols, rituals and beliefs for mentifacts. Examples of artifacts include buildings, tools, vehicles, and indeed anything that can be "classified according to the human needs and desires which they subserve - nourishment, health, shelter, clothing, enjoyment, adornment, communication, and so forth.". In other words, whereas mentifacts include the shared values and beliefs of a certain culture, sociofacts are about how these ideas are reflected in visible, societal structures, whereas artifacts constitute the material productions of a given culture. For the purpose of this paper, the definition of artifacts will be narrowed down to artistic productions, as I am interested in those products that target our imagination and emotions. Figure 1 shows a schematic representation of this typology.

An example of a sociofact in both France and The Netherlands includes Judeo-Christian festivities, most notably Christmas. Both FN and PVV share the idea of the threat posed by a multicultural society, in which there is no longer any place for traditional religious festivities. A PVV member of parliament even speaks of a "cultural war against our identity." 7 The main idea is that by trying to be more inclusive towards non-Christian groups - for instance by calling Christmas the "winterfeest" (winter feast), or Easter eggs "verstopeitjes" ('Treasure Hunt' eggs), the traditional Christian aspects, and thereby 'our' culture, are being lost. This idea of secularisation with the aim of more inclusion (or perhaps just more commercial success) is also present in France, and strongly linked to the presence of the traditional crèches de Noël (Nativity Scenes) in public places and their (in)compatibility with laicism. The FN considers these nativity scenes to be part and parcel of French culture and strives to maintain them in public buildings such as town halls, even though France's lay principles and legislation forbid religious symbols in public buildings.

7 Zwarte Piet wet: https://www.pvv.nl/75-fj-related/harmbeertema/9440-zwarte-piet-wet.html 


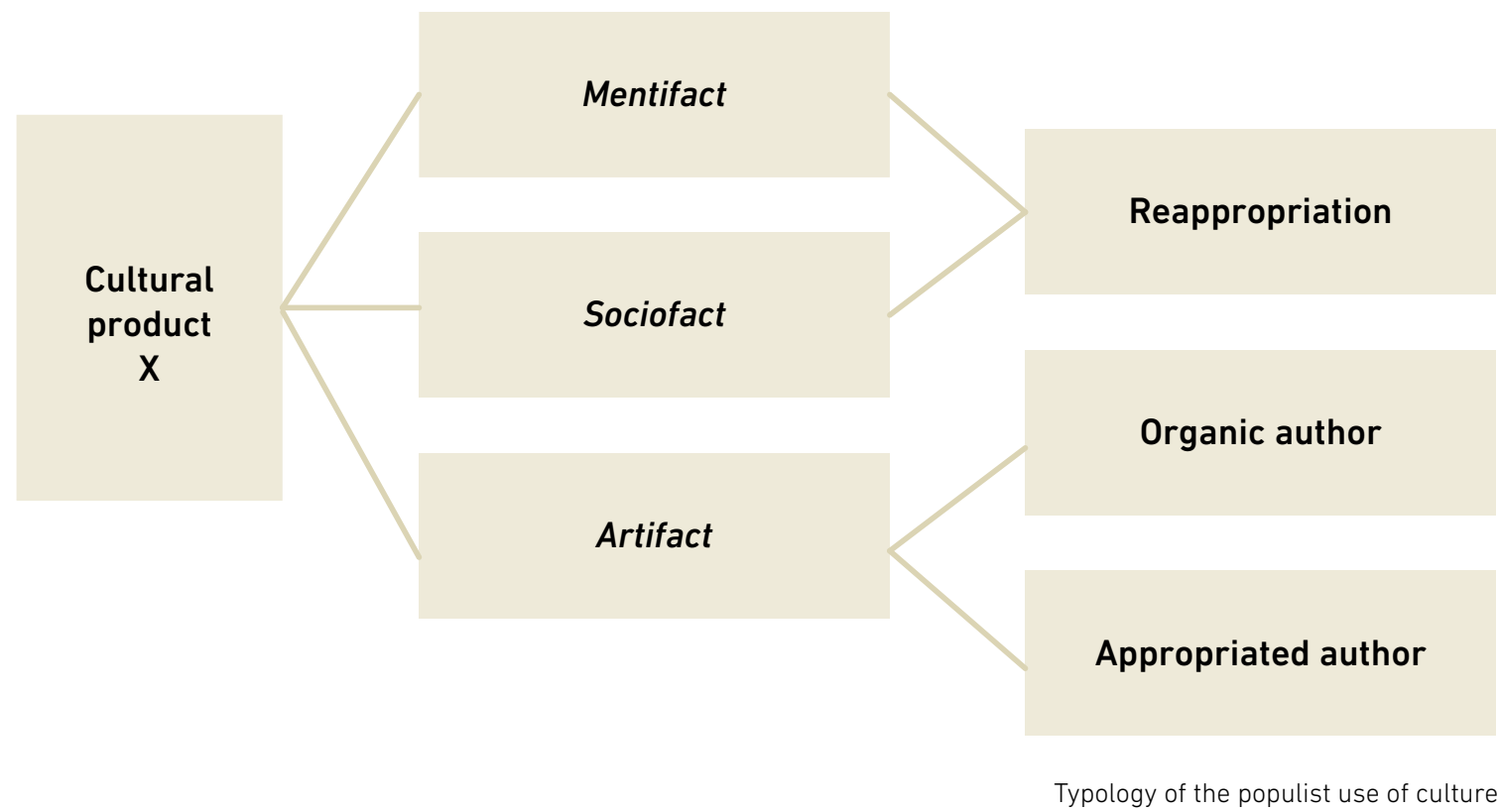

This idea of laicism, with its separation between State and Church, could be considered a mentifact, as it is an abstract value that is a key characteristic of French society. Institutionalised through the 1905 Act, this value took more specific form in the realm of sociofacts. However, it is important to note that it is not the 1905 Act but rather the underlying belief in laicism (dating back to The French Revolution) that often sparks fierce debate. An example is the burqini [bikini-cum-burqua] ban on some French beaches in the summer of 2016, which led to the police forcing Muslim women to remove the garment. Yet discussions have also arisen in other countries about the compatibility of 'our' Western society and 'their' religious symbols (for instance, in The Netherlands, where laicism is not explicitly enshrined in Law). In 2009, Geert Wilders introduced the notion of kopvoddentaks, or 'head rag tax', a highly pejorative name for a tax that would apply to those wearing head scarves in public. In general, we can observe an equivocal interpretation of laicism. In the case of Marine le Pen, this translates into the rejection of the principles of French laicism when it relates to the presence of certain religious objects that are part of the Judeo-Christian tradition, such as the afore-mentioned nativity scenes. However, when talking about Islam, she is a fierce defender of laicism, willing to ban Muslim head scarves. This shows how the idea of 'Identitarian Christianism' (cf. above) works in practice. The basic idea is that 'our' Judeo-Christian feasts and traditions (and which are part of our (European) culture) are under constant attack by other 'intolerant' religions and cultures, whose influence should be kept at bay (cf. Wodak et al. 2013).

An important feature that mentifacts and sociofacts have in common is the idea of the reappropriation of historical events, symbols or figures. This is in line with Renan's (1882) analysis of what defines a people: "having common glories in the past and a will to continue them in the present; having made great things together and wishing to make them again." This glorious past is constructed not only through recalling past glories but also by forgetting past disgraces. Renan considers the essence of a nation is that "all of its members have a great deal in 
common and also that they have forgotten many things." The concept of forgetting implies practical issues, like belonging to an ethnic group (whose origins are buried in the mists of time) that forgets shameful historical events, such as colonial wars, or in Renan's example, the St. Bartholomew's Day Massacre. Closely related to forgetting is Hobsbawm's notion of "invented traditions"; the construction of values and norms of behaviour, which are repeated and appear to be an unbroken continuation of the past (Hobsbawm 2012). In other words, a certain tradition (mentifact or sociofact) takes place regularly and exists presumably because things were done this way since time out mind. The problem lies not in the invented tradition but in the unshakeable (and mistaken) belief in its authenticity, the disregard of alternative pasts, and the idea that it must be followed in its 'pure form' if one is to stay true to one's culture. This, as we have seen above, makes invented traditions the playground of populist parties, claiming that 'others' and the 'elite' want to destroy these cultural manifestations, and with them, most of the national culture.

Anderson (2016: 210) underlines the importance of what he calls the emplotment of history, which is to say the creation of a historical narrative stressing an imagined fraternity, in which forgetting plays a crucial role:

"English history textbooks offer the diverting spectacle of a great Founding Father whom every schoolchild is taught to call William the Conqueror. The same child is not informed that William spoke no English, indeed could not have done so, since the English language did not exist in his epoch; nor is he or she told 'Conqueror of what?' For the only intelligible modern answer would have to be 'Conqueror of the English', which would turn the old Norman predator into a more successful precursor of Napoleon or Hitler."

This reappropriation of major historical events, figures or symbols is not only used to build the idea of a common national history but also to shape current challenges. To repeat Renan's words, it is the will to continue the glories of the past in the present. These challenges are linked to the presence of the alien 'other', the horizontal dichotomy, and both FN and PVV insist on the threat that Islam poses to French and Dutch (Judeo-Christian) values and beliefs. Interestingly, when looking at the speeches of populist leaders, one can find many parallels with historical events involving an 'us' and 'them' dichotomy.

Wilders refers to imperialism, calling Dutch citizens of Moroccan descent "colonists" "sharia-infiltration" 9 and hinting at the emergence of "Eurabia"10 during the final speech of his trial. Wilders also draws a historical parallel with Nazism, comparing The Koran to Mein Kampf, ${ }^{\mathbf{1 1}}$ stating that The Koran contains even more anti-Semitism and appeals to hate and violence than Mein Kampf. Newcomer Thierry Baudet (Forum voor Democratie) refers to Nazism in a slightly more subtle way, that is to say, without mentioning it explicitly. He stresses the 'purity' of civilisations, and warns against immigrants, who - according to him - are the reason for the "homeopathic dilution" or weakening of Western Civilisation.

Wilders' predecessor Pim Fortuyn, who was the first Dutch politician to openly question Islam and the multicultural society, was assassinated in 2002 . He spoke of the fights against Islamic fundamentalism

8 Inbreng Wilders tijdens ABP: https://www.pvv.nl/12-in-dekamer/spreekteksten/1288-inbreng-wilders-tijdens-apb. html

9 Wilders en De Graaf: Sharia verbieden is heel goed plan: https://www.pvv.nl/83-fj-related/machiel-de-graaf/6811wilders-en-de-graaf-sharia-verbieden-is-heel-goed-plan. html

10 Het laatste woord van Geert Wilders bij het proces: https:// www.pvv.nl/36-fj-related/geert-wilders/3939-het-laatstewoord-van-geert-wilders-bij-het-proces-sp-1560346816 $\mathrm{html}$

11 Interview Geert Wilders in het AD: https://www.pvv.nl/36fj-related/geert-wilders/9336-interview-geert-wilders-inhet-ad.html 
as 'crusades' $\mathbf{1 2}$, linking recent events to the mediaeval religious wars. His column ends with the words "History repeats itself, time after time".

In France, Marine Le Pen has compared the immigration crisis of 2015 to the barbarian invasions of the 4 th century ${ }^{\mathbf{1 3}}$, leading to the collapse of The Roman Empire. She implied that action was necessary in order to prevent the barbarians from reaching France, presumably to stop The French Republic and its modern civilisation coming to a sticky end.

The examples above show how a cultural narrative is constructed through a selection of mentifacts and sociofacts to stress the image of a powerful people versus an enemy in the present and near future. At the same time, this 'enemy' or 'other' is put in a much more negative light, using references to historical events bearing on the 'us' culture. The next part will discuss how artifacts contribute to the construction and confirmation of the populist narrative.

Looking at artifacts, we should distinguish between those that were created to support a populist discourse and those that were not. Based on the notion of "the organic intellectual" (Gramsci 1971) (that is to say, someone who identifies with (and speaks in the name of) a given class), I will refer to the first category as 'organic authors' and the second as 'appropriated authors'.

An example of an organic author that springs to mind when thinking of the Dutch case is a short film that was produced by Geert Wilders - Fitna (2008). The film is intended as a searing critique of Islam, showing fragments from The Koran next to footage of Islamic terrorism. Seeking to demonstrate

12 De geschiedenis herhaalt zich, keer op keer: http://www. pimfortuyn.com/16-islamisering/388-de-geschiedenisherhaalt-zich-keer-op-keer

13 Marine Le Pen compare la crise des migrants à la chute de l'empire romain: http://www.lefigaro.fr/politique/le-scan/ citations/2015/09/15/25002-20150915ARTFIG00111-marinele-pen-compare-la-crise-des-migrants-a-la-chute-de-lempire-romain.php the threat Islam poses to The Netherlands, the film is a continuation of Wilders' party programme, which seeks to ban Islamic influence. This harsh criticism of Islam and a strong defence of freedom of speech are perhaps what struck him when he read Oriana Fallaci's work. Wilders claimed that it was after reading Fallaci's The Force of Reason that he decided to found his own party ${ }^{\mathbf{1 4}}$. He also won the Oriana Fallaci Free Speech Award in 2009.

Another key event in Geert Wilders' political career was the murder of Dutch film director Theo van Gogh after the release of his Islam-critical film Submission in 2004. This film and the killing of van Gogh are a special case meriting more detailed study. It seems that Van Gogh could qualify as an 'organic author' but at the same time his murder has been appropriated by many others. The killing is a hot topic in the PVV and an important part of Wilders' Fitna. Interestingly, the above-mentioned 'literary populist' Leon de Winter wrote the novel VSV (2012) on the reappearance of Van Gogh as a guardian angel.

Two examples of French organic authors include Éric Zemmour and Renaud Camus. The former argued in his essay Le Suicide Français (2014), that mass (Muslim) immigration was leading to France losing its cultural identity and authenticity, hence the idea of a French suicide. This idea of cultural loss is put forward by Renaud Camus, author of Le Grand Remplacement in 2011. He theorises that the native population will be reverse-colonised by Muslim immigrants, thus 'mutating' the given country and its culture. An important aspect of this theory is the complicity of the political establishment at both the national and at the European level. With their generous immigration policies, driven by a supposed loathing of their native inhabitants, they would encourage people from Maghreb and Sub-Saharan Africa to move to Europe. Although this might sound a bit far-fetched - in fact, it was characterised as 'complotiste' (that is, as

\footnotetext{
14 Patriottische lente in Milaan: https://www.nrc.nl/ nieuws/2016/01/30/patriottische-lente-in-milaan1581420-a210117
} 
a 'conspiracy theory') by Marine Le Pen - Camus remains a source of inspiration for some PVV politicians, whom he joined on a demonstration march in January $2018^{15}$.

The second category of authors (that is, the 'appropriated authors') is best illustrated by French writer Michel Houellebecq. His latest novel Soumission (2015), in which the Islamisation of France in the near future is depicted, was used by populist actors and right-wing journalists to underline the cultural dangers we are facing, linking them to the ideas of Zemmour and Camus. However, a deeper analysis of the novel and the author's intentions reveals a different message. In fact, the novel is critical of the simplistic 'good versus bad' dichotomies characterising the populist discourse (Jansma 2018). In other words, although the novel was not intended as right-wing populist propaganda (indeed, quite the opposite), it was appropriated as such by FN populists. This shows how a novel can become a part of a political strategy, in which it is used to promote a given worldview and a linked political agenda.

\section{CONCLUSIONS}

This paper has analysed the various ways in which populist actors in France and The Netherlands engage with culture. Although populists often seem unenthusiastic about culture with a big ' $\mathrm{C}$ ' (which they dismiss as "left-wing hobbies" and argue that should not be subsidised by the tax-payer), the appropriation of cultural products is ever-present in their discourse. Culture has the power to connect a people (an imagined community) on the basis of shared values and beliefs but also to draw sharp lines between 'us' and 'them'. As such, a hegemony of cultures is constructed, which presupposes 'our' culture to be better than 'theirs'.

15 Kasteelheer slaat alarm over cultuur van Europa: https:// www.nrc.nl/nieuws/2018/01/22/kasteelheer-slaat-alarmover-cultuur-van-europa-a1589332
I have looked at populists' use and appropriation of culture. My purpose here was to come up with a typology of populism and culture. By first making the distinction between artifacts, mentifacts and sociofacts, one can get a more accurate idea of what 'culture' means. I have shown that mentifacts and sociofacts are prone to: reappropriation; notions of memory and oblivion (Renan); invented tradition (Hobsbawm); emplotment (Anderson). All of them are key mechanisms that need to be taken into account. As far as artifacts are concerned, I have suggested two categories - organic authors and appropriated authors. In the latter case, the interpretation of the artifact often seems at odds with what the author intended. Here, deeper analysis of both artifact and its reception is needed to establish whether this is indeed the case.

It should be said that any attempt to draw clear lines between artifacts, mentifacts and sociofacts is doomed to failure. While cultural categories are clear-cut, cultural products are often ambiguous and blur boundaries. Depending on the perspective, a cultural object could be both considered a mentifact and a sociofact. However, as we have seen above, we are interested not only in which kinds of cultural products make up the populist narrative but also how they are interlinked, and how they make up the whole populist narrative.

More research is needed to ensure systematic investigation of actual discursive practices of cultural appropriation. Specifically, this not only means analysing more cultural products but also scaling up analyses (for example, by using digital tools). Such an approach is needed to grasp how a variety of populist and non-populist actors engage with culture, and more precisely, which linguistic patterns and rhetorical devices can be found (cf. Jansma 2018; Wodak 2015). Not only will this give us the tools to decode the populist interpretation of cultural products but it will also reveal the importance of culture for the populist agenda. One hopes that such insights will lead to the building of a new, more inclusive cultural narrative. 


\section{BIBLIOGRAPHIC REFERENCES}

Anderson, B. (2016) Imagined Communities. Reflections on the Origin and Spread of Nationalism (2nd ed.) London: Verso

Barker, C. (2000). Cultural Studies. Theory and Practice. London: Sage Publications

Bauman, Z. From Pilgrim to Tourist - or a Short History of Identity (2011). In Du Gay, P., and Hall, S. (ed.). Questions of Cultural Identity. 18-36. Los Angeles: Sage Publications

Bax, S. (2016). De publieke intellectueel als literair populist. Het publieke schrijverschap van Leon de Winter. Nederlandse Letterkunde, 21 (2), p. 97-129.

Berg-Sørensen, A. (2017). 'Submission': ambiguity, hypocrisy and misanthropy in Michel Houellebecq's imaginary politics. Journal of Political Ideologies, 22 (2), p. 131-146.

Brubaker, R. (2017). Between nationalism and civilizationism: The European populist movement in comparative perspective. Ethnic and Racial Studies, 40 (8), 1191-1226

Furedi, F. (2018). Populism and the European Culture Wars. The Conflict of Values Between Hungary and the EU. Oxon: Routledge

Gidron, N. and Hall, P.A. (2017). The Politics of Social Status: Economic and Cultural Roots of the Populist Right. British Journal of Sociology, 68 (S1), S57-S84.

Goodhart, D. (2017). The Road to Somewhere. The populist revolt and the future of politics. London: Hurst and Co.

Gramsci, A. (1971). Selections from the prison notebooks. New York, NY: International Publishers.

Hall, S. (1985). Authoritarian Populism: A Reply. New Left Review, $O$ (151), 115-125.

Hall, S. (1986). Gramsci's Relevance for the Study of Race and Ethnicity. Journal of Communication Inquiry, 10 (2), 5-27.

Hart, G. (2012). Gramsci, Geography, and the Languages of Populism. In Gramsci: Space, Nature, Politics (301-320). Chichester; Malden, MA : Wiley-Blackwell.

Hobsbawm, E. Introduction: Inventing Traditions (2012). In Howsbawm, E. and Ranger, T. (ed.). The Invention of Tradition. 1-14. Cambridge University Press.

Huxley, J.S. (1955). Evolution, Cultural and Biological. Yearbook of Anthropology, (1955), p. 2-25.

Inglehart, R. and Norris, P. (2016) Trump, Brexit, and the Rise of Populism: Economic Have-Nots and Cultural Backlash. (Harvard Faculty Research Papers. Cambridge, MA: Harvard University.

Jansma, J. (2018). Populism and literature: Mapping the Debate on Houellebecq's Soumission. Perspectivas de la Comunicación 11(1) 7-56.

Judis, J. B. (2016). The Populist Explosion. How the Great Recession Transformed American and European Politics. New York: Columbia Global Reports.

Kriesi, H. et al. (2006). Globalization and the transformation of the national political space: Six European countries compared. European Journal of Political Research, 45, 921-956.

Laclau, E. (2005). On populist reason. London: Verso.

McGuigan, J. (1992). Cultural Populism. London: Routledge.

Moffitt, B. (2017). Liberal Illiberalism? The Reshaping of the Contemporary Populist Radical Right in Northern Europe. Politics and Governance, 5 (4), 112-122.

Mudde, C. (2004). The Populist Zeitgeist. Government and Opposition, 39(4), 541-563.

Mudde, C. and Kaltwasser, C. (2013). Exclusionary vs. Inclusionary Populism: Comparing Contemporary Europe and Latin America. Government and Opposition, 48 (2), 147-174.

Mudde, C. and Kaltwasser, C. (2017). Populism, a very short introduction. Oxford University Press.

Nachbar, J. and Lause, K., An introduction to the Study of Popular Culture: What is this Stuff that Dreams are Made Of? (1992). In Nachbar, J. and Lause, K. (ed.). Popular Culture. An Introductory Text. (1-35).Bowling Green State University Press.

Nagle, A. (2017). Kill All Normies. The online culture was from Tumblr and 4chan to the alt-right and Trump. John Hunt Publishing. 
Ossewaarde, M. (2014). The national identities of the 'death of multiculturalism' discourse in Western Europe. Journal of Multicultural Discourses, 9 (3), 173-189.

Paveau, M.-A. (1998). Le « roman populiste » : enjeux d'une étiquette littéraire. Mots. Les langages du politique, 55, 45-59.

Rau, P. Autumn after the referendum (2018). In Eaglestone, R. (ed.). Brexit and Literature. Critical and Cultural Responses. (15-30). Oxon: Routledge.

Renan, E. (1882) What is a Nation?, text of a conference delivered at the Sorbonne on March 11th, 1882, in Renan, E. Qu'est-ce qu'une nation? (1992). Paris: Presses-Pocket (translated by Ethan Rundell).

Rensmann, L. (2017). The Noisy Counter-Revolution: Understanding the Cultural Conditions and Dynamics of Populist Politics in Europe and the Digital Age. Politics and Governance, 5 (4) 123-135.

Rodrik, D. (2017). Populism and the economics of globalization. NBER Working Paper no. 23559.

Rooduijn, M., De Lange, S.L. and Van der Brug, W. (2014) A populist Zeitgeist? Programmatic contagion by populist parties in Western Europe. Party Politics 20 (4), 563-575.

Rooduijn, M., Van der Brug, W. and De Lange, S.L. (2016) Expressing or fuelling discontent? The relationship between populist voting and political discontent. Electoral Studies 43, 32-40.

Shaw, K. BrexLit. (2018). In Eaglestone, R. (ed.). Brexit and Literature. Critical and Cultural Responses. (15-30). Oxon: Routledge.

Wodak, R., Khosravinik, M. and Mral, B. (Eds.) (2013). Right-wing populism in Europe. Politics and discourse. London: Bloomsbury.

Wodak, R. (2015). The Politics of Fear. What Right-Wing Populist Discourses Mean. London: Sage.

\section{BIOGRAPHICAL NOTE}

Judith Jansma is a PhD candidate at the department of European Literature and Culture at the University of Groningen (NL). She holds a bachelor and a master in French Language and Culture (both University of Groningen). Her PhD project focuses on ways in which populists in France and the Netherlands engage with culture as a tool for identity construction. 